\title{
The Relationship Between the Learning Styles and Academic Performance of Medical Faculty Students
}

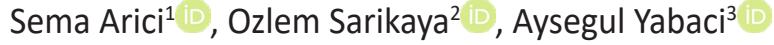 \\ 1 Biruni University Medical School, Department of Pathology, Istanbul, Turkey \\ 2 Marmara University Medical School, Department of Medical Education, Istanbul, Turkey \\ 3 Bezmialem Vakif University Medical School, Department of Biostatistics, Istanbul, Turkey \\ Correspondence Author: Sema Arici \\ E-mail: darici@biruni.edu.tr
}

Received: 05.01.2021

Accepted: 24.04 .2021

\begin{abstract}
Objective: Medical students have with different learning styles and different educational backgrounds. While the curriculum is being prepared, the success of students this situation should be considered. This study is designed to reveal the learning styles of the second-year medical students and to compare their academic performance with their learning style.

Methods: One hundred and four students of 2nd-year Bezmialem Vakif University Medical School are included in the study. To reveal the learning styles, Kolb's Learning Styles Inventory applied to all students. Also, the academic performance of each student was listed. We compared the statistical relationship between gender and academic performance with students' learning styles.

Results: Of the 104 students' there was 59 female, 45 male in gender. According to the questionnaire, most of the female and male students were assimilators (abstract-passive learners) (\%58.5) and divergers (concrete -passive) (\%28.8). Students' academic performance results were between 75-80. We did not find a statistically significant difference between gender and students'learning styles and academic performance results ( $p>0.05)$.

Conclusion: Identifiying and monitoring of students' learning styles in the universities especially in medical schools is neglected. However, we should know students' learning style in order to recognize their learning habits shaped by previous learning experiences and to improve their success. Moreover, it is important to improve students' performance by using learning strategies and methods suitable for different learning styles.

Keywords: Learning, Academic Test Performance, Education, Medical
\end{abstract}

\section{INTRODUCTION}

Learning is one of the most important abilities of human beings and takes place by constructing the information encountered by the individual in their own mind. One of the effective theories in professional education is the experimental learning theory proposed by David Kolb (1). Accordingly, learning is a process, and knowledge is created by the transformation of experiences. The source of thinking and reflections are appropriate cognitive and affective experiences; these ideas are organized and concentrated with pattern and concepts, new actions arise forintellectual transformation. According to Kolb this learning process represents a learning cycle that touches all the bases through the students' active experience, reflection and conceptualization. Therefore learning is not only cognitive, but also an adaptive process between the individual and their environment (2). In addition to these, it is important to know individual differences in the process of information processing. This situation, which is accepted theoretically but neglected in practice, has been the subject of various studies. Although it is accepted theoretically, this situation, which is neglected in practice, has been the subject of various studies (2-6). Learning style is one of the most important concepts that reveal individual differences in the learning process. Knowing a person's learning style enables learning to be orientated according to the preferred method. It is necessary to understand whether they are active or reflective when processing information, analytical or holistic while understanding information. Until today, different learning styles have been defined by many scientists and different scales have been developed to determine them. Among these, the most widely used is Kolb's learning styles scale (1$3)$. In this scale, each learning style has a different way of learning. In this respect, different levels and learning styles of students should be taken into consideration in educational practices $(1-3,8)$. 
In order to define the learning style, it is necessary to determine whether they prefer active or reflective processing for information, analytical or holistic prefer or intuitive way, visual or auditory tools while learning information, and to understand whether they are performing analytical or holistic processing. Until today, different scales for learning styles have been developed by many author. Among these, the most widely used is Kolb's learning styles inventory. Each learning style on the scale has a different learning pathway. The results of these studies brought attention to the fact that different levels and learning styles of students should be taken into consideration in educational practices $(1-3,8)$.

If teaching and learning environments are organized according to different cognitive and learning styles, targeted learning outcomes can be achieved. As different results have been obtained in studies conducted for this purpose, the relationship between the academic performance of the individual and the learning environment and the student's cognitive and learning style can be evaluated $(5,8,10)$. This study was planned to investigate the learning styles of Bezmialem Vakif University Medical Faculty (BVUMF) 2nd grade students and to evaluate the relationship between students' gender and academic performance with learning styles.

\section{METHODS}

One hundred four students attending the BVUMF as 2nd year students were included in the study. Kolb Learning Styles Inventory, which was created by D. Kolb and translated into Turkish by Askar and Akkoyunlu and whose validity and reliability study was conducted and applied in order to determine the learning styles of the students (1). The scale includes for sub - dimensions and 12 guestions in each them, a total of 48 items. For the four sub-items in each question, students are asked to give a score (between 1 and 4 points), giving 4 for the most appropriate option and 1 for the least appropriate. The scale is evaluated by collecting the 1st subitems as "concrete experinece", 2nd sub-items "reflective observation", 3rd sub-items "abstract conceptualization", and 4th sub-items "active experimentation".

In this way, a score between $12-48$ is obtained for 4 subitems. The next step is to acquire the reunited scores. With the help of 4 points obtained at this stage, two points of 4 are obtained (between -36 and +36 ) with the process of "abstract conceptualization - concrete experience" and "active experimentation - reflective observation". With the help of 4 points obtained at this stage, two points of 4 are obtained (between -36 and +36 ) with the process of "abstract conceptualization - concrete experience " and "active experimentation - reflective observation". Based on these points, the learning style of the person is determined according to the intersection of the two points. Matrix view of Kolb's learning styles is shown in Table 1.
Table 1. Kolb learning styles inventory

\begin{tabular}{|l|l|l|}
\hline & $\begin{array}{l}\text { Doing (Active } \\
\text { Experimentation-AE) }\end{array}$ & $\begin{array}{l}\text { Watching (Reflective } \\
\text { observation - RO) }\end{array}$ \\
\hline $\begin{array}{l}\text { Feeling (Concrete } \\
\text { Experience-CE) }\end{array}$ & Accomodating (CE/AE) & Diverging (CE/RO) \\
\hline $\begin{array}{l}\text { Thinking (Abstract } \\
\text { Conceptualization-AC) }\end{array}$ & Converging (AC/CE) & Assimilating (AC/RO) \\
\hline
\end{tabular}

\subsection{Diverging (feeling and watching $-C E / R O)$ :}

These people are able to look at things from different perspectives. They prefer to watch rather than do, tending to gather information and use imagination to solve problems. These people like to gather information and brainstorming and prefer to work in groups.

\subsection{Assimilating (watching and thinking $-A C / R O)$ :}

People who prefer this way wants good clear explanation rather than practical opportunity. They prefer logical approach and more interested in ideas and abstract concepts. People with this style prefer readings, lectures, exploring analytical models

\subsection{Converging (doing and thinking $-A C / A E$ ):}

These people prefer technical tasks and they are best at finding practical uses ideas and theories. They like to work with practical applications and solve problems by finding solutions to questions and problems.

\subsection{Accommodating (doing and feeling - CE/AE):}

They are attracted to new challenges and experiences. These people prefer to work in teams to complete tasks. This style learners tend to rely on others information than carry out their analysis. Action and initiative roles are required.

\subsection{Statistical analysis}

The distribution of the data was analyzed using the Shapiro Wilk test. The Kruskal Wallis test was used for comparing three or more groups that did not show normal distribution. Post hoc comparison of variables were found significant in the Kruskal Wallis test was made by Dunn's test. Pearson Chi-square or Fisher's Exact test was used for comparison of categorical data. Mann Whitney U test was used to compare variables that do not have a normal distribution between the two groups. Descriptive statistics of the data are given as median (minimum-maximum) and frequency (percentage). All statistical analyzes were carried out and reported in IBM SPSS Statistics 20.0 program and at $\alpha=0.05$ significance level.

\section{RESULTS}

Considering 104 students, distribution of the learning styles was found as 58 (55.8\%) "assimilating", 30 (28.8\%) "diverging", 11 (10.6\%) "converging" and 5 (4.8\%) "accomodating". 
According to gender, forty five of 104 students were male and 59 of them were female. The distribution of learning styles according to gender, is shown in Table 2.

Table 2. Distribution of Learning Styles by Gender

\begin{tabular}{|l|l|l|}
\hline Learning Style & Male & Female \\
\hline Accommodating & $4(8.9 \%)$ & $1(1.7 \%)$ \\
\hline Converging & $8(17.8 \%)$ & $3(5.1 \%)$ \\
\hline Diverging & $11(24.4 \%)$ & $19(32 \%)$ \\
\hline Assimilating & $22(48.9 \%)$ & $36(61 \%)$ \\
\hline p-value & $\mathbf{0 . 0 5 4}$ & \\
\hline
\end{tabular}

Averages of yearly academic performance was given as success score. Success score according to Accomodating, Converging, Diverging and Assimilating learning style was found as 75, 78, 80 and 75 respectively. No statistically significant difference was found between the learning styles and academic performances of the second grade students of the medical school ( $p>0.05)$.

The results of students' success score and learning styles by gender is given in Table 3. Statistically significant relationship was not found between the learning styles of male and female students and their academic performance $(p>0.05)$.

Table 3. Students' success score and learning styles by gender

\begin{tabular}{|l|c|c|c|c|c|}
\hline Gender & Accommodating & Converging & Diverging & Assimilating & p-value \\
\hline $\begin{array}{l}\text { Success } \\
\text { Score in } \\
\text { Male }\end{array}$ & 67 & 70 & 74 & 70 & 0.706 \\
\hline $\begin{array}{l}\text { Success } \\
\text { Score in } \\
\text { Female }\end{array}$ & 76 & 74 & 75 & 71 & 0.412 \\
\hline
\end{tabular}

\section{DISCUSSION}

Individuals develop appropriate learning strategies and styles through formal and social learning experiences (13,11 ). According to Dunn, who has conducted many studies on this subject, learning styles are "each student's use of a different and individual's self-directed way while learning and remembering new and difficult information" (12). Medical Students come from different educational environments and bring the habits they have gained with them. Inconsistencies between students the learning style and teaching style may negatively affect the students motivation, required effort, and learning outcomes $(3-5,8,11)$.

In our study, it was determined that more than half of the students were in the assimilating group in terms of learning styles. This was followed by the diverging group. In a study by Gürpınar et al. (3), the learning styles of students in different medical faculties were evaluated and it was found that they focused on the type of assimilating and diverging. These results are consistent with other studies on the subject. The characteristic of the assimilating group is that they prefer to learn by getting the information from its expert, and they prefer to learn by listening and watching to their instructors.
In Bezmialem Vakif University Faculty of Medicine, the fact that education is mainly conducted in the form of teachercentered lectures and this situation is compatible with the learning style of the assimilating group and it is not surprising that there is no difference between the academic performance of this groups. There is also no difference between the learning styles of other groups and their academic performances. Different learning styles, even if they are less in number, should be adopted to curriculum. This approach increases the success and flexibility of the education system, positively affects the student's self-confidence and participation in the learning process $(3,4,8)$. It is known that affective, visual and sequential learning features are predominant in medical students. Torrano et al revealed that those who were close to the sensing learning were more concrete-minded and prone to factual memorization in the lecture based teaching (5).

Students start their academic studies with different patterns of learning strategies; the charactersitics of these patterns change during their academic life and regarded as lifelong learning. Fabry et al noticed that most of the changes happen during the first term (11). As soon as they started to medical education, they study according to their prior learning experiences. Further changes refer to learning with colleagues. They learn how to be succesfull from their new learning environment. It is emphasized that this change can take place especially between 3-7 years. It has been shown that the students who have an assimilating style at the beginning of medical school can change their learning styles by active learning over the years. $(2,3,11)$. Gürpınar et al. also showed that, although some of the students have a distinctive learning style, according to curriculum and learning methods, students tend to learn more systematically (3). The relationship between learning styles and academic performance has been studied, mostly have shown no difference $(5,9,10,13)$. While the learners with reflective observation were successful in teamwork in problem solving, the intuitive learners were found to be more successful in basic medical sciences and clinical pathology than the others. In the study related to the success in anatomy lesson, the sensory style was found to be more dominant than the intuition. This result is not surprising, while sensory learners are better at memorizing and lab work (5). In our study, although most of the students have an assimilating learning style, statistically significant difference was not found between the academic performance and their learning styles. The students' average achievements are close to each other in all learning styles. This situation evaluated both in the annual course committee exams and final exams. In this case, we considered that regardless of their prior learning experiences and presumptions, they adapted to system with their new learning environment as Fabry et al indicated. Meantime, most of them contribute to the assimilating learning style and being passive listener. And as soon as they realize that they are successful in multiplechoice exams, their learning styles change. In the study of Lynch et al, a relationship was found between multiple choice questions and learning styles, but no difference was 
found between learning style and success in the clinical performance exams (13). It is not easy to predict what the result would be, if they were asked to analyze and synthesize the knowledge in the exams assessed clinical reasoning. In our study, no difference was found between the learning styles and gender. The assimilating learning style were used mostly in both genders. In addition, there is no difference between learning styles and academic performances for both gender. In some studies, while no difference was found in learning style between genders, Fabry et al have found that male students learn more visually $(2,5,14)$.

In our study, the research is a cross-sectional study that includes only second grade students and teacher-centered learning activities. Considering that learning styles can change with different teaching strategies and learning methods added to the curriculum, it can be thought that the research design to monitor the success and learning styles of these students over the years will give more detailed results for the purpose of the study.

\section{CONCLUSION}

In conclusion, program designs and teaching strategies that will provide opportunities for all different learning styles in education should be included to curriculum. Accordingly, assessment systems should be arranged in accordance with the principles of diversity, validity, reliability and equity according to the teaching strategy and learning areas.

The main goal should be to provide learning opportunities that will enable students not only to memorize factual information, but also to use what they have learned to solve different problems through analysis and synthesis.

\section{REFERENCES}

[1] Aşkar P, Akkoyunlu B. Kolb öğrenme stili envanteri. Eğitim ve Bilim. 1993; 87:37-47. (Turkish)

[2] Bitran M, Zuniga D, Pedral N, Padilla O, Mena B. Medical students' change in learning styles during the course of the undergraduate program: from 'thinking and watching' to 'thinking and doing'. Canadian Medical Education Journal 2012; 3(2):86-97.

[3] Gürpınar E, Batı H, Tetik C. Tıp Fakültesi öğrencilerinin öğrenme stillerinin belirlenmesi. Tıp Eğitim Dünyası 2011; 32: 18-29. (Turkish)

[4] Tatar E, Tatar E. Öğrenme stillerine dayalı öğretim. Journal of Quafaz University 2007; 126-130. (Turkish)

[5] Torrano D, Ali S, Chan C. First year medical students' learning style preferences and their correlation with performance in different subjects within medical course. BMC Medical Education 2017; 17: 1-7.

[6] Koşan, A, Demirören M, Kemahlı S, Palaoğlu Ö, Ayhan í. Ankara Üniversitesi Tıp Fakültesinde tıp eğitimine başlayan öğrencilerin öğrenme stilleri. Tıp Eğitim Dünyası 2007;41:618620. (Turkish)

[7] Felder R, Henriques ER. Learning and teaching styles in foreign and second language education. Foreign Language Annals 1995; 28: 21-31.

[8] Curry L. Cognitive and learning styles in medical education. Academic Medicine 1999; 74: 409-13.

[9] Tariq S, Khan MA, Afzal S, Shahzad SR, Hamza M, Khan HA et al. Association between academic learning strategies and annual examination results among medical students of King Edward Medical University. Annals of KEMU 2016;22: 124-34.

[10] Shirazi F, Heidari S. The Relationship Between Critical Thinking Skills and Learning Styles and Academic performance of Nursing Students. J Nurs Surg 2019;27:e38. 10

[11] Fabry G, Giesler M. Novice medical students: Individual patterns in the use of learning strategies and how they change during the first academic year. GMS Z Med Ausbild 2012; 29(4): Doc56.

[12] Dunn R, Giannitti MC,Murray JB,Rossi I,Geisert G, Quinn P. Grouping students for instruction: effects of learning style on achievement and attitudes. J Soc Psychol 1990; 130: 485-494.

[13] Lynch TG, WoelfI NN, Steele DJ, Hanssen CS. Learning style influences student examination performance. Am J Surg. 1998;176:62-66.

[14] Slater J, Lujan H, DiCarlo S. Does gender influence learning style preferences of first-year medical students? Adv Physiol Educ 2007;31(4):336-342. 